This is an accepted manuscript of a book chapter published by Routledge in Tuning The Past: Theory And Practice In The Music Of The Islamic World edited by Rachel Harris and Martin Stokes on 20 November 2017, available online: https://www.routledge.com/Theory-and-Practice-in-the-Music-of-the-Islamic-World-Essays-in-Honour/HarrisStokes/p/book/9781138218314

Accepted version downloaded from SOAS Research Online: http://eprints.soas.ac.uk/25381/

Theory and practice in contemporary Central Asian Maqām traditions: the Uyghur On Ikki Muqam and the Kashmiri Sūfyāna Musīqī

\author{
Rachel Harris, Department of Music, SOAS University of London
}

In a 1992 article, Owen Wright traces the changing modal nature of 'Segāh Maqām' across different historical periods. He argues that caution must be exercised in comparative studies of maquam across time and space; we should never assume that the use of the same name in theoretical treatises equates to the use of the same modal material in practice. In our occasional conversations about contemporary Central Asian maqām traditions, Wright was still more radical, and suggested more than once that in these traditions the maqām were little more than 'bins' or repositories for organising and storing repertoire.

This chapter considers the problem of theory and practice in Central Asian maqām traditions with reference to two distinct traditions: the Kashmiri Sūfyāna Musīqī and the Uyghur On 
This is an accepted manuscript of a book chapter published by Routledge in Tuning The Past: Theory And Practice In The Music Of The Islamic World edited by Rachel Harris and Martin Stokes on 20 November 2017, available online: https://www.routledge.com/Theory-and-Practice-in-the-Music-of-the-Islamic-World-Essays-in-Honour/HarrisStokes/p/book/9781138218314

Accepted version downloaded from SOAS Research Online: http://eprints.soas.ac.uk/25381/

Ikki Muqam. ${ }^{1}$ Both of these traditions pay homage to the Systematist School of music theory ${ }^{2}$ as it was transmitted to Central Asia, but they have also evolved over time, absorbing new layers of theorisation and new kinds of repertoire, and adapting to new contexts of performance. I speculate that the imposition of different forms of musical theory in the different locations may serve to mask deeper, unmarked, similarities in performance and aesthetics. I argue that the common features shared by these traditions are in part the heritage of a shared Central Asian theoretical tradition, but also a deeply sedimented set of shared musical practices and aesthetic preferences. Maqām traditions in this region are closely tied to Sufi traditions of vocal practice, and I suggest that these are more significant than the elite heritage of music theory in explaining the close musical relations between different regional maqām traditions.

\section{Contemporary repertoire}

If we take a look at the contemporary repertoires of these two traditions, we can note broad similarities between them. In terms of structure, both traditions comprise fixed suites with a modal profile, with an unmetered introduction - an instrumental shakl in Sūfyāna Musīqī, a

\footnotetext{
${ }^{1}$ The comparison was inspired by an international seminar, Synthesis of Raga and Maqam in Kashmiri musical culture held in Srinagar in June 2013. I am indebted to the organiser Dilorom Karomat and our hosts in the Centre of Central Asian Studies in Kashmir.

${ }^{2}$ By the $13^{\text {th }}$ century a joint Arab-Persian system of music was used through much of the Middle East and Central Asia. Its principal theorist was Safi-al Din Urmani of Baghdad who is generally regarded as the founder of the Systematist School; Wright 1978: pp. 1-19.
} 
This is an accepted manuscript of a book chapter published by Routledge in Tuning The Past: Theory And Practice In The Music Of The Islamic World edited by Rachel Harris and Martin Stokes on 20 November 2017, available online: https://www.routledge.com/Theory-and-Practice-in-the-Music-of-the-Islamic-World-Essays-in-Honour/HarrisStokes/p/book/9781138218314

Accepted version downloaded from SOAS Research Online: http://eprints.soas.ac.uk/25381/

sung muqüddimä in the On Ikki Muqam - followed by a series of named, metered pieces which move from longer and slower to faster and shorter metres; some of the pieces are followed by instrumental repeats or variations, called jawab in Sūfyāna Musīqī or märghul in the On Ikki Muqam. We cannot draw many conclusions from this. Suites structures (also termed 'cyclic' or 'compound forms') are widespread across Central Asia and beyond. Pacholczyk has suggested that the structure of the Sūfyāna Musīqi is most reminiscent of a $9^{\text {th }}$ century Andalusian suite form, ${ }^{3}$ while Chinese scholars like to compare the On Ikki Muqam with the $9^{\text {th }}$ century Daqu (Great Suites) of China's Tang dynasty court. ${ }^{4}$

We can also note the shared names of the maqām in both traditions: seven of the names of the On Ikki Muqam are also found amongst the Kashmiri maqām: Segah, Chahargah, Panjigah, Iraq, Nava, Ozzal, and Bayat. However, as Wright is quick to point out, just as we find in other related maquam traditions, the shared names do not necessarily imply that the modal material is the same. It is a moot point whether at some point in history the Kashmiri and Uyghur, or indeed Bukharan Nava Maqām, indicated the same modal material, or if these prestigious names were simply grafted onto local traditions of practice without necessarily indicating the same modal profile. ${ }^{5}$

\footnotetext{
${ }^{3}$ Pacholczyk 1996: p. 65.

${ }^{4}$ See, for example, Gu 1985.

${ }^{5}$ See, for example, Wright 1992: pp. 480-509.
} 
This is an accepted manuscript of a book chapter published by Routledge in Tuning The Past: Theory And Practice In The Music Of The Islamic World edited by Rachel Harris and Martin Stokes on 20 November 2017, available online: https://www.routledge.com/Theory-and-Practice-in-the-Music-of-the-Islamic-World-Essays-in-Honour/HarrisStokes/p/book/9781138218314

Accepted version downloaded from SOAS Research Online: http://eprints.soas.ac.uk/25381/

I have argued elsewhere that the On Ikki Muqam have existed less as an actual repertoire and more as an idealised framework - derived from the Central Asian theoretical tradition which surrounds a much more fluid oral tradition, from which individual musicians learn, perform, and vary different parts, and into which musicians might slot their own local repertoires and compositions. ${ }^{6}$ This loose web of musical practices crosses different contexts of life, many of which are directly related to traditions of Sufism. As I will argue below, this shared Sufi heritage may be particularly significant in explaining shared musical elements within the Kashmiri Sūfyāna Musīqī and the On Ikki Muqam. However, the $20^{\text {th }}$ century development of the On Ikki Muqam serves to obscure this understanding of the repertoire, and hence its links with Sūfyāna Musīīì.

\section{Central Asian Theoretical Traditions}

The very name On Ikki Muqam (Twelve Maqām) seems to identify this repertoire as a direct descendent of the Systematist tradition, which was transmitted in the Central Asian context through a chain of theoretical musical treatises. Prominent examples in this written tradition include the Risāla-i Musīq $\bar{\imath}$ by Nishāpūri, written in Khorasān in the late $12^{\text {th }}$ to early $13^{\text {th }}$ centuries. This text is one of the earliest Persian language treatises on music, and it is the first to give the names of the twelve 'parda', a term later used interchangeably with maqām. According to Nishāpūrī’s text, Bārbad (c.585- 629), the famous musician of the Sassānian

\footnotetext{
${ }^{6}$ Harris 2008.
} 
This is an accepted manuscript of a book chapter published by Routledge in Tuning The Past: Theory And Practice In The Music Of The Islamic World edited by Rachel Harris and Martin Stokes on 20 November 2017, available online: https://www.routledge.com/Theory-and-Practice-in-the-Music-of-the-Islamic-World-Essays-in-Honour/HarrisStokes/p/book/9781138218314

Accepted version downloaded from SOAS Research Online: http://eprints.soas.ac.uk/25381/

court of Khusrau Parviz, created seven parda, which were augmented to twelve by his students. $^{7}$

Also important in the Central Asian theoretical tradition are two major treatises on music written by Abd al-Qadir al-Maraghi (d. 1435). Maraghi, who was brought by Timur ${ }^{8}$ from Baghdad to Samarqand, is regarded as the first major Timurid theorist. It is in his writings that the term maqām first becomes fully established. Wright argues that Maraghi played a significant role in determining the norms of Timurid art music, in essence by transmitting the shared Islamic art music idiom from Baghdad to Samarqand and subsequently to Herat. ${ }^{9}$ A version of this tradition was transmitted to Bukhara following the fall of the Timurid empire. Prominent texts from Bukhara include the $16^{\text {th }}$ century treatise by Najm ad-Dīn Kavkabī, and the $17^{\text {th }}$ century text by Darvish Ali Changi. ${ }^{10}$ From their writings emerges a simplified modal system in which the twelve maqām serve as the foundation from which the shu 'ba (branches) and $\bar{a} v \bar{a} z$ (voices) were derived. ${ }^{11}$

\footnotetext{
${ }^{7}$ Sumits 2013: p. 5 .

${ }^{8}$ Timur emerged as the most powerful ruler in the Muslim world in the late $14^{\text {th }}$ century after defeating the Mamluks of Egypt and Syria, the emerging Ottoman Empire and the declining Sultanate of Delhi. He founded the Timurid Empire, and cultivated a reputation as a patron of art and architecture.

${ }^{9}$ Wright 1996.

${ }^{10}$ Alexandre Djumaev has published extensively on these texts. In English, see Djumaev 1992 and 1997.

${ }^{11}$ Sumits 2011: pp. 76-7.
} 
This is an accepted manuscript of a book chapter published by Routledge in Tuning The Past: Theory And Practice In The Music Of The Islamic World edited by Rachel Harris and Martin Stokes on 20 November 2017, available online: https://www.routledge.com/Theory-and-Practice-in-the-Music-of-the-Islamic-World-Essays-in-Honour/HarrisStokes/p/book/9781138218314

Accepted version downloaded from SOAS Research Online: http://eprints.soas.ac.uk/25381/

To what extent did this theoretical tradition communicate itself to the lesser centres of Central Asia - Kashgar and Kashmir - and to what extent was it maintained in these centres through the $18^{\text {th }}$ and $19^{\text {th }}$ centuries? We know from Józef Pacholczyk's detailed study that the Kashmiri Sūfyāna Musīqī tradition possesses several $18^{\text {th }}$ century theoretical treatises and anthologies which link it firmly to this Central Asian tradition of musical theory. These include the Karāmat-e-Majrā ('Marvel of Courses') which Djumaev has identified as in part copied directly from $16^{\text {th }}$ century Bukharan manuscripts. ${ }^{12}$

For the On Ikki Muqam, the primary surviving historical text is the Tavārikh-i Musīqīyyūn (History of Musicians), written by Mulla Mūjiz in 1854-5 on the request of the Shah of Khotan. A 1919 copy of this text was found in Khotan in 1950, and it has since become of great importance to Uyghur music history. ${ }^{13}$ Like the Kashmiri texts, this source also explicitly draws on earlier Persian and Arab language musical treatises. It offers no theoretical musical description, but it does provide a genealogical account of a lineage of master musicians stretching back to Fīsāghūrs (Pythagoras) and including, amongst others, Abd ar-Rahmān Jāmī of the Timurid court in Herat, who is said to have created Ajam Maqām and was the teacher of Ali-Shīr Navầ'̄i, who created Navā Maqām. The text demonstrates that this Eastern Turki writer, like most Central Asian authors between the $13^{\text {th }}$ and $20^{\text {th }}$ centuries, drew in his histories on the valued cultural traditions that were part of the Islamic synthesis. ${ }^{14}$

\footnotetext{
${ }^{12}$ Pacholczyk 1996: pp. 45-8.

${ }^{13}$ Baytur \& Tömür 1982.

${ }^{14}$ Light 2008: p. 162.
} 
This is an accepted manuscript of a book chapter published by Routledge in Tuning The Past: Theory And Practice In The Music Of The Islamic World edited by Rachel Harris and Martin Stokes on 20 November 2017, available online: https://www.routledge.com/Theory-and-Practice-in-the-Music-of-the-Islamic-World-Essays-in-Honour/HarrisStokes/p/book/9781138218314

Accepted version downloaded from SOAS Research Online: http://eprints.soas.ac.uk/25381/

In many ways, the figure of Ali-Shīr Navā' $’ \overline{1}$ exemplifies this Central Asian tradition. Navā' was a key cultural figure of the Timurid era, a high-ranking and wealthy official under the Timurid ruler Husayn Bāyqarā (1438-1506). With his numerous ghazal and historical works, he is today more commonly seen as the outstanding classical poet of the Turkic languages rather than, in Mūjiz's conception, as a composer of maqām. He is claimed as a culture hero by both Uzbeks and Uyghurs, and his ghazal feature prominently in the contemporary Uyghur On Ikki Muqam repertoire. But his works do not fit comfortably into modern nationalist narratives. His texts are particularly praised for their seamless and sophisticated incorporation of Arabic and Persian vocabulary into the Turkic, providing a ready demonstration of the Central Asian Islamic synthesis:

Ärabi guft'äm zähkät, bi farsi guft'äm khändät,

Bi turki sözlisäm külküng bu aläm mushki-bar olsun.

Ärabi guft'äm sidrät, bi farsi guft'äm sinät,

Bi turki sözlisäm köksung qizil alma, anar olsun....

If I say in Arabic 'your laugh' and if I say in Persian 'your laugh,'

And if I say in Turki 'your laugh,' let this world be your fragrant hair.

If I say in Arabic 'your breast' and if I say in Persian 'your breast,'

And if I say in Turki 'your breast,' let it be a red apple, a pomegranate... ${ }^{15}$

\footnotetext{
${ }^{15}$ Chebiyat Muqam: muqüddimä (attributed to Navā'̂̄), excerpt, as performed by Sanubar Tursun, Edinburgh festival, 2014. Translated by Rachel Harris and Aziz Isa.
} 
This is an accepted manuscript of a book chapter published by Routledge in Tuning The Past: Theory And Practice In The Music Of The Islamic World edited by Rachel Harris and Martin Stokes on 20 November 2017, available online: https://www.routledge.com/Theory-and-Practice-in-the-Music-of-the-Islamic-World-Essays-in-Honour/HarrisStokes/p/book/9781138218314

Accepted version downloaded from SOAS Research Online: http://eprints.soas.ac.uk/25381/

Although it is not explicit, Mūjiz's writing suggests a dual understanding of maqām, both as a modal system that composers would use for singing a poetical text, and also as a particular composition. ${ }^{16}$ This reflects the period in which he was writing (the mid-19 $9^{\text {th }}$ century) which may be characterised as a period of transition between two understandings of maqām. Up to the $18^{\text {th }}$ century, Central Asian theoretical texts present maqām as a modal system, as conventions of melody and modulation that form the basis for musicians to create, improvise, and vary their own unique musical expressions. By the $20^{\text {th }}$ century in Central Asia we find this idea largely replaced by the idea of maqām as repertoire, exemplified by the large-scale suites known as the Shash Maqām of Bukhara, and the On Ikki Muqam of Kashgar-Yarkand. Today these large-scale suites serve as national symbols of the Uzbek and the Uyghur nations. The historical transformations they have undergone can be understood as processes of canonisation. ${ }^{17}$

\section{Processes of Canonisation}

In the mid-1950s, soon after the Chinese Communist Party had established its rule in the Uyghur region, the new authorities set up a project to preserve and order the On Ikki Muqam. They chose one musician to provide the raw material: a respected Muqam performer named Turdi Akhun. According to a 1960s biography, Turdi Akhun was born into a hereditary

\footnotetext{
${ }^{16}$ For example, he separates the canonical $15^{\text {th }}$ century shu 'ba systems: Dūgāh, Sīgāh, Chahārgāh, from Pahlavān Muhammad's compositions based in them; see Light 2008: p.164.

${ }^{17}$ Harris 2008.
} 
This is an accepted manuscript of a book chapter published by Routledge in Tuning The Past: Theory And Practice In The Music Of The Islamic World edited by Rachel Harris and Martin Stokes on 20 November 2017, available online: https://www.routledge.com/Theory-and-Practice-in-the-Music-of-the-Islamic-World-Essays-in-Honour/HarrisStokes/p/book/9781138218314

Accepted version downloaded from SOAS Research Online: http://eprints.soas.ac.uk/25381/

family of musicians near Kashgar in 1881, and he wandered with his satar (bowed lute) on his back between the cities of Kashgar, Yarkand and Khotan for 50 years before being discovered by Communist Party cultural workers. He was invited to participate in recording sessions in the mid-1950s. Staff transcriptions of these recordings were published in 1960, which constituted the first notations of the On Ikki Muqam tradition. ${ }^{18}$

Following the hiatus of the Cultural Revolution, a succession of transcriptions, audio and video recordings were published. Today, Muqam performance is taught in the Xinjiang Arts College. A state-funded Muqam Research Committee and Muqam Ensemble employ over one hundred musicians, dancers and singers. They have toured extensively around China and internationally, and more recently successfully solicited UNESCO support with the 2005 proclamation of the 'Uyghur Muqam' on the list of Masterpieces of the Oral and Intangible Heritage of Humanity.

Figure 2: Turdi Akhun demonstrating Muqam to the masses in the 1950s

Contemporary Chinese and Uyghur musicologists draw primarily on Western classical musical theory to describe and explain the On Ikki Muqam, and published transcriptions use staff notation. Thus, for example, the characteristic 'limping' rhythms found in some parts of

\footnotetext{
${ }^{18}$ Shinjang 1960, p. 1.
} 
This is an accepted manuscript of a book chapter published by Routledge in Tuning The Past: Theory And Practice In The Music Of The Islamic World edited by Rachel Harris and Martin Stokes on 20 November 2017, available online: https://www.routledge.com/Theory-and-Practice-in-the-Music-of-the-Islamic-World-Essays-in-Honour/HarrisStokes/p/book/9781138218314

Accepted version downloaded from SOAS Research Online: http://eprints.soas.ac.uk/25381/

the repertoire - discussed in more detail below - are rendered as a form of hemiola. ${ }^{19}$ Chinese musicologists also sometimes draw on Chinese theoretical traditions, describing - for example - the 'unstable' or fluctuating pitches characteristic of some of the Muqam as 'huoyin' (lively notes), a term derived from southern Chinese instrumental genres. ${ }^{20}$

Under the current political instability in Kashmir, the Sūfyāna Musīqī musicians can only dream of the levels of state support currently enjoyed by the musicians of the On Ikki Muqam tradition, ${ }^{21}$ but the $20^{\text {th }}$ century history of Sūfyāna Musīqī does show evidence of local attempts to embark on the work of canonisation. In 1983, a Kashmiri musician, Sheikh Abdul Aziz, produced a new theorisation of Sūfyāna Musīqī in his Ramūz-e-Mūsīqū (Secrets of Music). This new theorisation drew on multiple sources: on musicians' practice, on the $18^{\text {th }}$ century Central Asian-style treatises mentioned above, and on the theoretical traditions of Indian classical music. Aziz used the Hindu system of thāt to describe the scales; he drew on the Karāmat-e-Majrā to describe a hierarchy of maqām and link them to extra-musical phenomena such as the zodiac, and therapeutic powers; and he described the rhythmic modes of Sūfyāna Musīqī in terms of tāla, mātra, and drum patterns $(b o l s) .{ }^{22}$ Pacholczyk argues that Aziz produced his new theory under pressure to legitimise Sūfyāna Musīqi practice, and that the use of Indian classical theory was primarily introduced in order to please the largely

\footnotetext{
${ }^{19}$ See, for example, Shinjang 1994.

${ }^{20}$ Zhou 1995.

${ }^{21}$ It was clear from the 2013 conference in Srinagar that contemporary musicians are indeed dreaming of obtaining greater state support for the tradition.

${ }^{22}$ Pacholczyk 1996: pp. 116-7.
} 
This is an accepted manuscript of a book chapter published by Routledge in Tuning The Past: Theory And Practice In The Music Of The Islamic World edited by Rachel Harris and Martin Stokes on 20 November 2017, available online: https://www.routledge.com/Theory-and-Practice-in-the-Music-of-the-Islamic-World-Essays-in-Honour/HarrisStokes/p/book/9781138218314

Accepted version downloaded from SOAS Research Online: http://eprints.soas.ac.uk/25381/

Hindu intellectual elite of the time. ${ }^{23}$ Thus we see similar processes at work on both repertoires in the $20^{\text {th }}$ century, drawing their theorisation away from the Islamic tradition, and towards different traditions of musical theory.

In $20^{\text {th }}$ century Xinjiang, we also find evidence of the incorporation of new repertoires into the framework of the On Ikki Muqam. The canonisation of the On Ikki Muqam, and its elevation to the status of national icon, involved a number of choices. The process privileged the repertoire of certain performers over others; it also involved juxtaposing and synthesising separate performances by different musicians. When the first notations were published in the 1960s, the contents, the names, even the number of the On Ikki Muqam varied in different musicians' repertoires. Much of the extensive work of research and composition undertaken over the past few decades has been done with the aim of restoring, or recreating, the full complement of twelve suites that - it is widely assumed - once existed. A cursory look at the available historical sources suggest that this popular view is questionable at the least.

\section{Cosmopolitan Courts and Sufi Shrines}

The prevalent discourse on the On Ikki Muqam holds that their roots date back to the preIslamic period; that is to the $3^{\text {rd }}$ to $9^{\text {th }}$ century Buddhist kingdoms which occupied the same territory as today's Xinjiang region. In this interpretation, the Arabo-Persian language terminology that they currently employ is simply a more recent grafting on of theoretical

\footnotetext{
${ }^{23}$ Pacholckyk 1996: p. 119.
} 
This is an accepted manuscript of a book chapter published by Routledge in Tuning The Past: Theory And Practice In The Music Of The Islamic World edited by Rachel Harris and Martin Stokes on 20 November 2017, available online: https://www.routledge.com/Theory-and-Practice-in-the-Music-of-the-Islamic-World-Essays-in-Honour/HarrisStokes/p/book/9781138218314

Accepted version downloaded from SOAS Research Online: http://eprints.soas.ac.uk/25381/

terms onto an ancient, indigenous body of music. This geographically static, historically deep-rooted, and typically nationalist account appears quite at odds with Mūjiz's genealogies. The nationalist account does, however, pay homage to Mūjiz in its emphasis on two historical figures of the $16^{\text {th }}$ century Yarkand Khanate. This khanate is today widely regarded as a key historical point in the transmission of the On Ikki Muqam. It is also a period when the links between Kashgar and Kashmir are prominent in the historical record.

One of the oldest extant Uyghur historical texts is Mirza Haydar Dughlat's 1541 Tarikh-i Rashidi. Mirza Haydar took part in a military campaign waged by Sultan Sa'id of Yarkand against Tibet. They set out with an army of 5000 in the year 1531, crossed the Karakorum pass, fought as far as Ladakh, then returned to spend the winter in the Muslim kingdom of Kashmir. They were hosted by its ruler, Sultan Muhammad Shah, who married his daughter to Sa'id as a sign of the warm relations between the two kingdoms. On his way back to Yarkand, Sa'id died of altitude sickness on the mountain pass, his son Abdurashid took the throne, and Mirza Haydar went into exile in Kashmir. There he wrote, in the scholarly lingua franca of Persian, his history of the Yarkand Khanate, Tarikh-i Rashidi, named after the ruler who had exiled him. ${ }^{24}$

The period of Abdurashid's rule (1533-1560), for which Mirza Haydar is the principal source, is portrayed today as a golden age in Uyghur history, a cultural flowering. In the course of his rule, Abdurashid concluded treaties with the Khanate of Bukhara and the

\footnotetext{
${ }^{24}$ Bellew 1999: p. 39.
} 
This is an accepted manuscript of a book chapter published by Routledge in Tuning The Past: Theory And Practice In The Music Of The Islamic World edited by Rachel Harris and Martin Stokes on 20 November 2017, available online: https://www.routledge.com/Theory-and-Practice-in-the-Music-of-the-Islamic-World-Essays-in-Honour/HarrisStokes/p/book/9781138218314

Accepted version downloaded from SOAS Research Online: http://eprints.soas.ac.uk/25381/

Moghul Empire. He welcomed, and granted land to, the Naqshbandi Sufi teacher Ahmad Kasani, also known as Makhdum-i 'Azam (the Great Master), from Samarqand. This marked the beginning of the political ascendancy of the Naqshbandi Sufis in this region. ${ }^{25}$ We can see from Mūjiz's brief account that the Yarkand court of this period was musically cosmopolitan, participating in the elite musical and literary culture shared across Central Asia. The last two musical masters in Mūjiz's genealogy are attached to this court: Qidir Khan Yarkandi and Amannisa Khan, wife of the Sultan. Mūjiz writes of musicians coming from as far afield as Iraq to study with Qidir Khan, and he devotes considerable space to the Sultan's wife, Amannisa Khan, who is described as the composer of the no longer extant Maqām 'Ishrat-i Angiz, and an outstanding singer and performer on the satar, with whom the Sultan was passionately in love. These two figures are widely regarded by contemporary Uyghurs as the direct transmitters of today's On Ikki Muqam.

Figure 3: Still from a 1980s film on the life of Amannisa Khan, featuring Qidir Khan Yarkandi (centre, holding a modern satar), and an arrangement of musicians, choir and dancers that owes much to contemporary styles of professional troupe performance. ${ }^{26}$

In many ways we might see this period in Yarkand as equivalent to the earlier reign of Sultan Zain al-'Ābidīn (1420-70) in Kashmir, which is also regarded as a cultural golden age. Zain al- 'Ābidīn was a connoisseur and patron of music; his court was cosmopolitan and renowned

\footnotetext{
${ }^{25}$ Elias 1898.

${ }^{26} \mathrm{http}: / /$ people.cs.pitt.edu/ mehmud/uyghur/music_dance.html (accessed 14/2/2015).
} 
This is an accepted manuscript of a book chapter published by Routledge in Tuning The Past: Theory And Practice In The Music Of The Islamic World edited by Rachel Harris and Martin Stokes on 20 November 2017, available online: https://www.routledge.com/Theory-and-Practice-in-the-Music-of-the-Islamic-World-Essays-in-Honour/HarrisStokes/p/book/9781138218314

Accepted version downloaded from SOAS Research Online: http://eprints.soas.ac.uk/25381/

for its music and dance. Under his rule, several schools of music were founded in Kashmir. They invited musicians from Iran and Central Asia who were responsible for introducing Persian and Central Asian musical elements into Kashmiri practice. Pacholczyk speculates that many features of today's Sūfyāna Musīqī could be a result of this $15^{\text {th }}$ century Central Asian influence. ${ }^{27}$

Undoubtedly these elite histories are significant in drawing both traditions into the wider sphere of elite Islamic musical theory and practice, but we should also take into account the many other points of contact over the ensuing centuries, which might provide scope for the sharing and exchange of musical practices and ideas. Regular contacts were maintained between Kashmir and the region now known as Xinjiang - for that period more appropriately termed Altishahr (the six cities that ringed the Taklamakan desert) - through diplomacy, trade, and itinerant Sufis. Srinagar seems to have served Uyghurs as a place of exile, from the time of Mirza Haydar well into the $20^{\text {th }}$ century, and traders regularly crossed the mountain passes between them. Just 20 years after Mūjiz wrote his Tavārikh-i Musīqüyyūn, the British diplomat Henry Bellew travelled the route from Srinagar to Kashgar in 1873 as part of a diplomatic mission, ${ }^{28}$ and produced an account of the journey written to delight a British public fascinated with this newly accessible exotic realm. From his account we can see that

\footnotetext{
${ }^{27}$ Pacholczyk 1996: pp. 26-7.

${ }^{28}$ A mission sent from British India to establish relations with Yaqub Beg, the military leader from Ferghana who temporarily took Altishahr out of Qing imperial control in the late $19^{\text {th }}$ century.
} 
This is an accepted manuscript of a book chapter published by Routledge in Tuning The Past: Theory And Practice In The Music Of The Islamic World edited by Rachel Harris and Martin Stokes on 20 November 2017, available online: https://www.routledge.com/Theory-and-Practice-in-the-Music-of-the-Islamic-World-Essays-in-Honour/HarrisStokes/p/book/9781138218314

Accepted version downloaded from SOAS Research Online: http://eprints.soas.ac.uk/25381/

trade between the two regions was well established in the late $19^{\text {th }}$ century. Bellew notes the patterns of export from Altishahr:

The wool of Turfan and the musk of Khutan were exported to Kashmir, the one for the manufacture of its peculiar shawls, the other for the drug market of India. ... whilst the hemp resin, or bang, of Yarkand formed the principal item of export in the direction of Kashmir and the Panjob. ${ }^{29}$

Figure 3: Map. (Detail) 1903 Map of Central Asia made by European traveller Sven Hedin, showing Yarkand and Srinigar.

Arguably, the most direct correspondences between these two musical traditions can be traced to their relationship with the Sufi tradition, a relationship that encompasses both the elite literary tradition and popular religious practices at Sufi shrines. In his Tavārikh-i Musīqūyyūn, Mūjiz places strong emphasis on music as a mystical form of religious practice. He describes a majlis (gathering) held at the $16^{\text {th }}$ century court of Babur in Kabul, at which Mavlānā Sāhib Balkhī picked up his tanbūr and began playing Chöl Iraq Maqām. After he passed the second $a v j$ [musical climax] and reached the third, a nightingale came and perched on the tuning pegs of the tanbür and began to sing, causing the people at the majlis to shout, weep, faint, and roll about. Mūjiz also describes Navā'î falling unconscious, overcome by

\footnotetext{
${ }^{29}$ Bellew 1999: pp. 67.
} 
This is an accepted manuscript of a book chapter published by Routledge in Tuning The Past: Theory And Practice In The Music Of The Islamic World edited by Rachel Harris and Martin Stokes on 20 November 2017, available online: https://www.routledge.com/Theory-and-Practice-in-the-Music-of-the-Islamic-World-Essays-in-Honour/HarrisStokes/p/book/9781138218314

Accepted version downloaded from SOAS Research Online: http://eprints.soas.ac.uk/25381/

ecstasy, while singing his own ghazals. Both Navā'̄i and his shaykh 'Abd ar-Rahmān Jāmī, were in fact followers of the Naqshbandi Sufi order, ${ }^{30}$ and much of Navā' '’’'s poetry is redolent of images of madness, the wine shop, the rose and its thorns: all common themes of the Sufi allegory. In contemporary professional performance and published versions of the On Ikki Muqam there have been efforts to reduce the number of explicitly religious and mystical texts, but even so, many of the texts commonly used in the On Ikki Muqam, like Navā'î's ghazal cited above, are still coloured with Sufi imagery.

Sūfyāna Musīqī uses a mixture of Persian and Kashmiri language poetic texts. The Persian texts are primarily attributable to the major Sufi poets such as Hafiz and Rumi. We know that at least up until the mid-20 $0^{\text {th }}$ century Uyghur singers also performed the On Ikki Muqam to a mixture of Turkic and Persian language texts, although the $20^{\text {th }}$ century reforms have exorcised the Persian texts and replaced them with canonical Chagatay Turkic poetry. It is entirely feasible that the same Persian texts were shared by both traditions until the 1950s. The Kashmiri texts are equally influenced by Sufi imagery, expressing common tropes such as the longing for mystical union with the Divine (wisal), the mystical journey through worlds, and the wine bearer who brings divine ecstasy:

Oh my Friend, come and save my life I am like a river, please come and bathe in it

\footnotetext{
${ }^{30}$ Founded by Baha-ud-Din Naqshband Bukhari (1318-1389).
} 
This is an accepted manuscript of a book chapter published by Routledge in Tuning The Past: Theory And Practice In The Music Of The Islamic World edited by Rachel Harris and Martin Stokes on 20 November 2017, available online: https://www.routledge.com/Theory-and-Practice-in-the-Music-of-the-Islamic-World-Essays-in-Honour/HarrisStokes/p/book/9781138218314

Accepted version downloaded from SOAS Research Online: http://eprints.soas.ac.uk/25381/

You have bought me as a slave, please come and save my life. ${ }^{31}$

Süfyāna Musīqī is traditionally performed in Sufi gatherings (mehfil) associated with the Qādirī order (which was established in Baghdad in the $12^{\text {th }}$ century by Shaikh 'Abd al-Qādir Gīlanī). This was the last major Sufi order to be introduced to Kashmir, in the late $16^{\text {th }}$ century. It remains the largest order in Kashmir today although it has come under pressure from reformists and Islamists in recent decades. Mehfil usually take place in private houses, and may take the form of weekly evening gatherings that include music and food, or all-night gatherings on religious holidays. Sūfyāna Musīqī was performed by a special caste of lowstatus professional hereditary musicians, hired to perform at the mehfil. They guarded their musical knowledge from exploitation by outsiders, but did not develop virtuosic performance techniques; musicians were judged by their command of the repertoire of poems, their ability to select the right poem to suit the mood of the mehfil, and to communicate its emotion effectively. ${ }^{32}$ Pacholczyk comments that some maqām might provoke the gathered dervishes to tears, and some might achieve ecstasy even though no actual $d h i k r$ was performed. ${ }^{33}$ Although Pacholczyk does not mention it, even to the present day, Sūfyāna Musīqī is also performed weekly at some of the shrines of Sufi saints around Kashmir. ${ }^{34}$

\footnotetext{
${ }^{31}$ Pacholczyk 1996: p. 30.

${ }^{32}$ Pacholczyk 1996: pp. 31-2. The limited description of the social context provided by Pacholcyzk suggests a set of relationships and practices similar to those described by Regula Burckhardt Qureshi in her rich study of Qawwali in the context of Sufi samā' ritual (2006).

${ }^{33}$ Pacholczyk 1996: p. 40.

${ }^{34}$ M. K. Raina, personal communication, Srinagar, June 2013.
} 
This is an accepted manuscript of a book chapter published by Routledge in Tuning The Past: Theory And Practice In The Music Of The Islamic World edited by Rachel Harris and Martin Stokes on 20 November 2017, available online: https://www.routledge.com/Theory-and-Practice-in-the-Music-of-the-Islamic-World-Essays-in-Honour/HarrisStokes/p/book/9781138218314

Accepted version downloaded from SOAS Research Online: http://eprints.soas.ac.uk/25381/

The Qādirī order is also widespread in Uyghur communities in contemporary Xinjiang. It spread into the Uyghur region from the neighbouring Ferghana valley in today's Uzbekistan, and is primarily active in the Kashgar-Yarkand area. Adherents hold weekly gatherings in Sufi lodges (khaniqa) and in private homes. These rituals include melodic prayers, dhikr and $\operatorname{sam} \bar{a}:$ However, unlike the Kashmiri Qādirī mehfil, their rituals do not use musical instruments. The Chishti order, which came to Khotan in the $19^{\text {th }}$ century, spread by merchants from India and Afghanistan, is better known for the musicality of its $s a m \bar{a} \cdot 35$ This order has a large following in India, Pakistan and Afghanistan, where it is famous for the explicit use of Qawwali music in its $s a m \bar{a}$ rituals. ${ }^{36}$ Its followers in Khotan have maintained the practice of using musical instruments (including plucked lutes and percussion) to accompany $s a m \bar{a}$ ' rituals, but what they play is very different from Qawwali, and more closely related to parts of the On Ikki Muqam. ${ }^{37}$

The songs of the $\operatorname{sam} \bar{a}$ 'rituals of the Uyghur Chishti Sufis are principally associated with a group of people known as ashiq: the Sufi mendicants who congregate at the shrines of Islamic saints which are found across Xinjiang, but especially in Khotan. These shrines

\footnotetext{
${ }^{35}$ For further details on Sufi orders in Xinjiang, see Zarcone 2002: pp. 534-41.

${ }^{36}$ For detailed discussion of Qawwali in Afghanistan see Baily 1988. For Pakistan, see Burckhardt Qureshi 2006.

${ }^{37}$ Clips of this kind of $s a m \bar{a}$ ' ritual can be seen on the website 'Sounding Islam in China', http://www.soundislamchina.org/?p=778 (accessed 16/2/2015).
} 
This is an accepted manuscript of a book chapter published by Routledge in Tuning The Past: Theory And Practice In The Music Of The Islamic World edited by Rachel Harris and Martin Stokes on 20 November 2017, available online: https://www.routledge.com/Theory-and-Practice-in-the-Music-of-the-Islamic-World-Essays-in-Honour/HarrisStokes/p/book/9781138218314

Accepted version downloaded from SOAS Research Online: http://eprints.soas.ac.uk/25381/

(mazar) are ubiquitous in the landscape, and form a key part of religious practice in the region; even small villages have holy graves, and the shrines of more important figures are the focus of large-scale pilgrimage, and the site of huge festivals held annually to celebrate the birthday of the saint ${ }^{38}$ They are often believed to be built where Islamic martyrs fell in battle, but in fact many are built on ancient Buddhist sites. Thus many of them are found deep in what is now inhospitable desert, constructed when the place was fertile. These are not major monuments like the shrine of Yasavi in Turkestan or the shrine of Moinuddin Chishti in Ajmer; most have survived the centuries marked only by a few flag poles - remarkable testaments to the strength and tenacity of community memory. ${ }^{39}$

Amongst the Uyghurs the meaning of ashiq (literally 'lover') differs somewhat from meanings in other parts of the Islamic world. ${ }^{40}$ The ashiq are religious mendicants and musicians who can still today be found across the Xinjiang region, singing in town bazaars and especially congregating at the shrines where pilgrims are generous with their charity. At festivals, people crowd around the ashiq as they sing and pray, seeking the blessings (baraka) that are thought to accrue from their presence. The signature instruments of the ashiq are the simple sapaya percussion sticks, made from wood or ibex horn and hung with a pair of metal

\footnotetext{
${ }^{38}$ Over the past few decades these shrine festivals have been periodically restricted under the tight controls on religious practices in Xinjiang.

${ }^{39}$ See Thum 2014 for further details on the shrines and associated pilgrimage tradition.

${ }^{40}$ The ashiq bards of eastern Turkey and Azerbaijan, for example.
} 
This is an accepted manuscript of a book chapter published by Routledge in Tuning The Past: Theory And Practice In The Music Of The Islamic World edited by Rachel Harris and Martin Stokes on 20 November 2017, available online: https://www.routledge.com/Theory-and-Practice-in-the-Music-of-the-Islamic-World-Essays-in-Honour/HarrisStokes/p/book/9781138218314

Accepted version downloaded from SOAS Research Online: http://eprints.soas.ac.uk/25381/

rings, but they may also play tash, a pair of flat stones struck together, and sometimes frame drums and plucked lutes, usually the rawap or tämbur. ${ }^{41}$

Figure 4. Ashiq at the Imam Hasim shrine festival near Khotan, 1990. Photo courtesy of Rahile Dawut.

The term ashiq appears to be a relatively modern usage for the people once more commonly known as dervishes or qalandar, perhaps adopted to avoid the stigma now associated with these terms. The British diplomat Henry Bellew encountered a group during his visit to Yarkand in 1873:

As we proceed, we come to a group of men and boys around a party of dancing dervishes. The rogues brave the cold in their tatters, and drown care in the wild song of their calling, and free life of their selection. They wear a high-peaked conical hat with a bushy edging of fur, and carry a leopard, or antelope, or other skin hanging on the back. Swung in front is the beggars' trough [a hollow gourd for drinking?], and in the hand is

\footnotetext{
${ }^{41}$ Harris \& Dawut 2002; Harris 2009. See also the film by Liu Xiangchen: Ashiq: The Last
} Troubadour (The View Culture \& Media, 2009). 
This is an accepted manuscript of a book chapter published by Routledge in Tuning The Past: Theory And Practice In The Music Of The Islamic World edited by Rachel Harris and Martin Stokes on 20 November 2017, available online: https://www.routledge.com/Theory-and-Practice-in-the-Music-of-the-Islamic-World-Essays-in-Honour/HarrisStokes/p/book/9781138218314

Accepted version downloaded from SOAS Research Online: http://eprints.soas.ac.uk/25381/

a stout club, or an iron mace set with jingling bells [sapaya]. This last is the music that accompanies their song, and gives the time to their step in the dance. ${ }^{42}$

A somewhat different picture emerges from a local Uyghur scholar's account of qalandar and dervishes, written in the early $20^{\text {th }}$ century by Muhammad Ali Damollah of Kashgar, and translated by the Swedish missionary, Gunnar Jarring. Damollah distinguishes carefully between the 'true' dervishes who do not accept money, and the many liars, beggars and cheats who imitate them. The 'true' dervishes perform dhikr and recite hikmat (the poetry of Ahmed Yasavi), and they say 'we are united with God in the same way as rain-water is joined with river-water'. ${ }^{43}$ Damollah's description of qalandar repeats the distinction between 'true' qalandar and thieves. 'True' qalandar play the sapaya, perform a whirling dance, and sing the poetry of the $17^{\text {th }}$ century mendicant mystic and poet Baba Rahim Mashrab. ${ }^{44}$

Although they have been often conflated with secular beggars, and although historical accounts are sparse, the ashiq or qalandar of Altishahr are surely related to the Sufi Qalandariyya order, which is recorded in Islamic histories since the $11^{\text {th }}$ century. Mongol rule facilitated their spread from Turkey and Egypt into Central Asian and India from the $14^{\text {th }}$

\footnotetext{
${ }^{42}$ Bellew 1875: pp. 278-9. The English missionaries Mildred Cable and Francesca French also write colourfully of a group of qalandar (ashiq) encountered in the bazaar in the eastern town of Turpan in the 1930s; Cable \& French 1942: p. 193.

${ }^{43}$ Jarring 1987: pp. 14-6.

${ }^{44}$ Jarring 1987: pp. 24-6.
} 
This is an accepted manuscript of a book chapter published by Routledge in Tuning The Past: Theory And Practice In The Music Of The Islamic World edited by Rachel Harris and Martin Stokes on 20 November 2017, available online: https://www.routledge.com/Theory-and-Practice-in-the-Music-of-the-Islamic-World-Essays-in-Honour/HarrisStokes/p/book/9781138218314

Accepted version downloaded from SOAS Research Online: http://eprints.soas.ac.uk/25381/

century onwards. In early Persian language accounts, the Qalandariyya are portrayed as people intoxicated by qalb (tranquillity of the heart), who reject social norms, pray and fast, and actively seek to violate orthodox behaviour. They believed that only by reducing oneself to a beggar could one experience the real value of spiritual involvement. The $11^{\text {th }}$ century Persian poet and mystic Baba Tahir writes:

I am the mystic gypsy called Qalandar;

I have neither fire, home nor monastery.

By day I wander about the world, and at night

I sleep with a brick under my head. ${ }^{45}$

As Alexandre Papas (2010) describes, the qalandar generally occupied a marginal place among conventional Muslims, admired by some for their spiritual exploits but feared and mistrusted for their disobedience to conventional law and social norms. Though many mystics adhered closely to orthodox Islam while pursuing their more esoteric practice, others lived unconventional lives, self-consciously breaking religious rules in order to gain mystical insight. ${ }^{46}$ The Qalandariyya often found themselves in a hostile relationship with the settled khaniqa life of other Sufi orders, but in places they also seem to have merged with more settled orders, and formed hybrid orders, such as the Qalanderiyya-Chishtiyya of northern India. ${ }^{47}$ The itinerant qalandar seem to have moved quite freely across Central Asia in the $18^{\text {th }}-19^{\text {th }}$ centuries. Another British traveller, Henry Landsell tells of a group of qalandar from Kashgar whom he encountered in 1882, 'prancing about the streets' of Khiva (in

\footnotetext{
${ }^{45}$ Rizvi 1983: p. 301.

${ }^{46}$ See also Baldick 1989: pp. 98-9; Algar 1999: pp. 1-16.

${ }^{47}$ Rizvi 1983: p. 303.
} 
This is an accepted manuscript of a book chapter published by Routledge in Tuning The Past: Theory And Practice In The Music Of The Islamic World edited by Rachel Harris and Martin Stokes on 20 November 2017, available online: https://www.routledge.com/Theory-and-Practice-in-the-Music-of-the-Islamic-World-Essays-in-Honour/HarrisStokes/p/book/9781138218314

Accepted version downloaded from SOAS Research Online: http://eprints.soas.ac.uk/25381/

today's western Uzbekistan), singing 'sacred songs in Persian and Turki, shouting as loudly as possible, accompanying the singing with boundings, prostrations, and whirling about'. ${ }^{48}$ The Diwani-i Mashrab, a popular collection of ecstatic poetry and tales from oral tradition, chronicles the wanderings of the major $18^{\text {th }}$ century mystic poet and qalandar Baba Rahim Mashrab as he travelled between Bukhara to Yarkand, urinating on the thrones of kings, defecating in mosques, and delighting in confounding the everyday morality of the time. ${ }^{49}$

\section{Ashiq and the On Ikki Muqam}

These itinerant Sufi mendicants may seem far removed from the low-status but respectable urban musician caste who perform the Sūfyāna Musīqīi ${ }^{50}$ They seem a still less likely source for the formation of a national musical canon, but we know that their songs are closely related musically to parts of the On Ikki Muqam as it is sung on the professional stage today, in particular the free-metered opening muqäddimä section and final mäshräp metered dance sections of the On Ikki Muqam. ${ }^{51}$ As I will argue below, these are the sections of the Muqam which also share prominent stylistic attributes with the Sūfyāna Musīqī repertoire. Interviews with contemporary Uyghur musicians confirm the relationship between the ashiq and the On

\footnotetext{
${ }^{48}$ Lansdell 2011: pp. 484-5.

${ }^{49}$ For a detailed discussion and annotated translation, see Papas 2010.

${ }^{50}$ The Kashmiri scholar Mushtaq Kaw suggests that the Kashmiri Rishis are related with the 'ascetics' (presumably the ashiq) of Xinjiang, though he does not provide any evidence for this claim; Kaw 2010: p. 253. See Ramsey 2012: pp. 197-200 for further discussion of the Rishi.

${ }^{51}$ Zhou 1999: pp. 248-266.
} 
This is an accepted manuscript of a book chapter published by Routledge in Tuning The Past: Theory And Practice In The Music Of The Islamic World edited by Rachel Harris and Martin Stokes on 20 November 2017, available online: https://www.routledge.com/Theory-and-Practice-in-the-Music-of-the-Islamic-World-Essays-in-Honour/HarrisStokes/p/book/9781138218314

Accepted version downloaded from SOAS Research Online: http://eprints.soas.ac.uk/25381/

Ikki Muqam. Abdurishit, the son of a well-known $20^{\text {th }}$ century Muqam performer, Qadirazi Muhämmät, told me:

My father, in order to learn muqam, mäshräp and many other things, wherever there were $a s h i q$, wherever there were dervishes he would go to learn with them ... and in that way he learned the full muqam. The ashiq know the mäshräp well. ${ }^{52}$

Qawul Akhun, the son of Turdi Akhun, also describes how his father:

... would go to a gulkhan, which is a house where they sold meat and tea and smoked $n \ddot{a s h a ̈ ~[h a s h i s h] ~ . . . ~ H e ~ w e n t ~ w i t h ~ t h e ~ i n t e n t i o n ~ o f ~ l e a r n i n g ~ m a ̈ s h r a ̈ p ~ s o n g s, ~ b u t ~ t h e y ~}$ would not let him in if he did not smoke näshä. All of the performers were ashiq. ${ }^{53}$

Unsurprisingly, this version of the transmission of the Uyghur national canon is not privileged in official accounts but it attests to the close, and recent, links between the ashiq repertoire and the On Ikki Muqam. The links appear still clearer when we consider the source of much of the poetry of the mäshräp sections of the Muqam: the ghazal of the region's bestloved qalandar, Baba Rahim Mashrab (in the modern Uyghur pronunciation: Mäshräp). Much of this poetry is in the ecstatic mystic tradition:

Ishqida köymäs hechkim diwana bolmaghunchä,

\footnotetext{
${ }^{52}$ Interview, Almaty, July 2003.

${ }^{53}$ Light 2008: p. 113.
} 
This is an accepted manuscript of a book chapter published by Routledge in Tuning The Past: Theory And Practice In The Music Of The Islamic World edited by Rachel Harris and Martin Stokes on 20 November 2017, available online: https://www.routledge.com/Theory-and-Practice-in-the-Music-of-the-Islamic-World-Essays-in-Honour/HarrisStokes/p/book/9781138218314

Accepted version downloaded from SOAS Research Online: http://eprints.soas.ac.uk/25381/

Shäm ‘idä yanmas hechkim pärwanä bolmaghunchä,

Söymäs sädäpni hechkim durdanä bolmachunchä,

Ädhäm supät dunyadin biganä bolmaghunchä

No one will burn in love unless he is insane,

No one will burn in a candle flame unless he is a moth,

No one will love an oyster unless there is a pearl,

No one will be like Adam until they forget the world. ${ }^{54}$

Another couplet by Mashrab that appears in Turdi Akhun's rendition of mäshräp songs, but has been eliminated from the revised editions, makes the links with the qalandar perfectly explicit:

Män qäländär shahimän, aläm manga wäyranädur,

Paytäkhti gülkhänim, ordam qäländär khanädur.

I am the king of the qalandar, the world is desolate to me,

My capital is the hashish house, my court is the place of the qalandar..$^{55}$

\section{Musical style and instrumentation}

I now turn back to the two repertoires as they are performed today, in order to highlight some of the similarities between them. Both genres are traditionally performed by a group of male voices supported by bowed and plucked lutes, zither and percussion. The bowed sāz-e-

\footnotetext{
${ }^{54}$ Translation by Nathan Light 2008: p. 113.

${ }^{55}$ Light 2008: p. 288.
} 
This is an accepted manuscript of a book chapter published by Routledge in Tuning The Past: Theory And Practice In The Music Of The Islamic World edited by Rachel Harris and Martin Stokes on 20 November 2017, available online: https://www.routledge.com/Theory-and-Practice-in-the-Music-of-the-Islamic-World-Essays-in-Honour/HarrisStokes/p/book/9781138218314

Accepted version downloaded from SOAS Research Online: http://eprints.soas.ac.uk/25381/

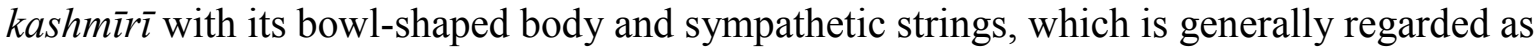
unique to Kashmir, is in fact very similar to the Dolan ghijäk, a type of large bowed lute still used in one regional form of Uyghur Muqam which has escaped the modernisation undergone by most other Uyghur instruments in the $20^{\text {th }}$ century. ${ }^{56}$

\section{Figure 5. Dolan ghijäk}

\section{Figure 6. Sāz-e-kashmīrī}

In Sūfyāna Musīīi the santur hammered zither takes a central position in the ensemble, usually played by the lead musician, whereas the lead role in Uyghur ensembles is traditionally taken by the bowed satar long-necked lute or the tämbur plucked lute. This kind of small, hammered zither is now rarely found in Uyghur amateur ensembles, but they feature more strongly in early $20^{\text {th }}$ century recordings from the region. ${ }^{57}$ The On Ikki Muqam is

\footnotetext{
${ }^{56}$ They differ slightly in the construction of the body, and in that the sāz-e-kashmìrì has three melodic strings of gut or metal, while the Dolan ghijäk has one melodic string of horsehair. One of the two tuning pegs visible in the picture is cosmetic; tuning pegs are called qolaq (ears), and 'an instrument must have two ears' (interview, Yasin Muhpul, August 2000). For details of the sāz-e-kashmìrī see Pacholczyk 1996: p. 38; for the Uyghur ghijäk, see Trebinjac 2000: pp. 200-5.

${ }^{57}$ See, for example, Before the Revolution: A 1909 recording expedition in the Caucasus and Central Asia by the Gramophone Company (British Library Sound Archive, 2002). Larger hammered dulcimers called chang, identical to the Chinese yangqin, are commonly used in contemporary large Uyghur professional troupes.
} 
This is an accepted manuscript of a book chapter published by Routledge in Tuning The Past: Theory And Practice In The Music Of The Islamic World edited by Rachel Harris and Martin Stokes on 20 November 2017, available online: https://www.routledge.com/Theory-and-Practice-in-the-Music-of-the-Islamic-World-Essays-in-Honour/HarrisStokes/p/book/9781138218314

Accepted version downloaded from SOAS Research Online: http://eprints.soas.ac.uk/25381/

accompanied by the small frame drums (dap, doira) that are found widespread around Central Asia, whereas the dokra used in Sūfyāna Musīqī are identical to Indian tabla, and use the same techniques and technical vocabulary.

Some aspects of musical style found in the Sūfyāna Musīqī repertoire appear to link them directly to the sections of the On Ikki Muqam which come from the ecstatic songs of the ashiq. In both traditions, the unmetered introductory sections - the muqäddimä of the On Ikki Muqam and the shakl in Sūfyāna Musīqi - lay out the tonal and melodic material of the maqām. Both the Kashmiri and Uyghur instruments are tuned to diatonic scales but the voices often use microtonal intervals. The realisation of the melodic line and details of ornamentation in these sections, especially by the bowed lutes - the sāz-e-kashmīri and the Uyghur satar - are strikingly similar with their characteristic use of slides up or down a third or a fourth, and sustained vibrato.

\section{Figure 7. Melodic detail in sāz-e-kashmīrī performance ${ }^{58}$}

Also of note is a more specific correspondence: in certain maqām in both traditions, the third and seventh steps of the scale are what we might term 'unstable' or fluctuating pitches: played higher in ascending passages, lower in descending passages. This is not a unique

\footnotetext{
${ }^{58}$ Transcribed from a short excerpt in the documentary film Mann Faqeeri, directed by M. K. Raina
} (2012). 
This is an accepted manuscript of a book chapter published by Routledge in Tuning The Past: Theory And Practice In The Music Of The Islamic World edited by Rachel Harris and Martin Stokes on 20 November 2017, available online: https://www.routledge.com/Theory-and-Practice-in-the-Music-of-the-Islamic-World-Essays-in-Honour/HarrisStokes/p/book/9781138218314

Accepted version downloaded from SOAS Research Online: http://eprints.soas.ac.uk/25381/

phenomenon; it is also found in genres of Arabic music where such pitches are termed mutaghayyir ('changeable'). Pacholczyk notes that in Sūfyāna Musīīi the singers raise or lower the pitch by microtonal intervals, while musicians either play the nearest available diatonic note causing a clash, or omit these pitches on their instruments. ${ }^{59}$ In the On Ikki Muqam these fluctuating pitches are always performed on instruments with vibrato; possibly a neater solution to the same problem. In Nawa muqäddimä in the On Ikki Muqam, for example, the third and seventh steps are fluctuating pitches, oscillating between two pitches a semitone apart. This is easily observed in a version performed by Abdulla Mäjnun on the bowed diltar; here the third step oscillates between $\mathrm{F}$ (with vibrato below to $\mathrm{E}$ ) and $\mathrm{F}$ sharp (with vibrato above to $\mathrm{G}$ ), and the seventh shifts between $\mathrm{B}$ (with vibrato above to $\mathrm{C}$ ) and $\mathrm{B}$ flat (with vibrato below to A). ${ }^{60}$

Figure 8. Nawa Muqam, muqüddimä (excerpt), instrumental version performed on the bowed diltar lute by Abdulla Mäjnun.

In terms of rhythm, there are striking correspondences between metres found in the later sections of both the On Ikki Muqam and the Sūfyāna Musīqī suites. Of note in the Sūfyāna Musīqi tradition are two metres (tala) which are placed at end of the suites: setāla and

\footnotetext{
${ }^{59}$ Pacholczyk 1996: pp. 68-9.

${ }^{60}$ For biographical details, and further analysis of Abdulla Mäjnun's performance style, see Harris 2008: pp. 45-66.
} 
This is an accepted manuscript of a book chapter published by Routledge in Tuning The Past: Theory And Practice In The Music Of The Islamic World edited by Rachel Harris and Martin Stokes on 20 November 2017, available online: https://www.routledge.com/Theory-and-Practice-in-the-Music-of-the-Islamic-World-Essays-in-Honour/HarrisStokes/p/book/9781138218314

Accepted version downloaded from SOAS Research Online: http://eprints.soas.ac.uk/25381/

chapāndāz. ${ }^{61}$ Both of these metres are discussed as if they contain beats of equal length, but in performance some beats are lengthened. Thus the metre chapāndāz is described by musicians as being of six beats (mätras): $1+2+3$, following a system of stroke elaboration taken directly from Indian tabla technique. Pacholczyk comments that while this could normally be rendered in the Western classical tradition in a time signature of $6 / 8$, what he hears in performance is $14 / 16$, thus:

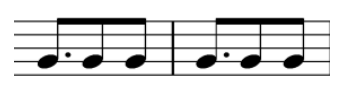

The setāla metre is theorised as twelve mātras: $3+3+3+3$ but, according to Pacholczyk, is rendered in performance as $28 / 8$ (or four bars of $7 / 8$ ), thus:

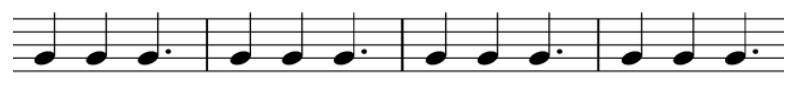

Heard in performance, these are evidently types of 'limping rhythms', which are also very characteristic of the mäshräp sections of the On Ikki Muqam. A 'limping' three-beat (i.e. with a lengthened final beat) is the more natural way to conceive both of these rhythms, but in the transcriptions below I have followed Pacholczyk's suggestion, which is also usual practice in modern Uyghur musicology, and transcribed them in 7/8 with use of hemiola (two quavers in the space of three).

\footnotetext{
${ }^{61}$ Pacholczyk 1996: p. 64.
} 
This is an accepted manuscript of a book chapter published by Routledge in Tuning The Past: Theory And Practice In The Music Of The Islamic World edited by Rachel Harris and Martin Stokes on 20 November 2017, available online: https://www.routledge.com/Theory-and-Practice-in-the-Music-of-the-Islamic-World-Essays-in-Honour/HarrisStokes/p/book/9781138218314

Accepted version downloaded from SOAS Research Online: http://eprints.soas.ac.uk/25381/

Figure 9: Rak Muqam, first mäshräp, excerpt, sung by Abdulla Mäjnun (transcribed an octave above actual pitch). ${ }^{62}$

Compare this with an excerpt from the setāla section of Segah Maqām in Sūfyāna Musīqī, transcribed according the same convention:

Figure 10. Segah Maqām, setāla, excerpt, sung by Ustad Muhammad Yaqoob Sheykh and his students, Srinigar 2013, (transcribed an octave above actual pitch).

Any attempt to transcribe these rhythms into a regular metre inevitably involves the artificial imposition of a constraining framework, which belies their flexibility. Jean During provides detailed analytical investigation and discussion of these kinds of rhythms in Tajik-Uzbek and Baluchi traditions, which are clearly related to the phenomenon in Uyghur and Kashmiri traditions. During argues that in these rhythms we are dealing with beats of two, or even three, different lengths within a single cycles, and prefers to term them 'ovoid' (egg-shaped rather than circular) rhythmic cycles. ${ }^{63}$ Alexandre Djumaev notes that the limping asymmetrical rhythms which are systematised in the Tajik-Uzbek maqām traditions, such as the talqincha, are closely linked to the trance-inducing rhythms of Sufi dhikr rituals (2002:

\footnotetext{
${ }^{62}$ Mäjnun: Classical Traditions of the Uyghurs (SOASIS, 2004).

${ }^{63}$ During 1997. See also Benjamin Koen's discussion of rhythm and affect in Badakhshani ritual maddoh performance; Koen 2005.
} 
This is an accepted manuscript of a book chapter published by Routledge in Tuning The Past: Theory And Practice In The Music Of The Islamic World edited by Rachel Harris and Martin Stokes on 20 November 2017, available online: https://www.routledge.com/Theory-and-Practice-in-the-Music-of-the-Islamic-World-Essays-in-Honour/HarrisStokes/p/book/9781138218314

Accepted version downloaded from SOAS Research Online: http://eprints.soas.ac.uk/25381/

937). The phenomenon of limping rhythms is not confined to Central Asian traditions; if we look further west, we again find the limping rhythms of courtly traditions closely related to Sufi samā' practices. Walter Feldman provides a detailed discussion of the aksak semā' $i$ rhythm (the term is likely etymologically linked to the Sufi samā) in the Ottoman repertoire, which he believes to be derived from the Mevlevi ritual, and possibly linked to Central Asian traditions. ${ }^{64}$ While contemporary more formalised Turkish aksak rhythm cycles do not display the striking 'ovoid' nature of the Central Asian limping rhythms, in this volume, Ekinci suggests that during the 18th century Semai usul may have been performed with an uneven internal division, i.e., as an ovoid rhythm. ${ }^{65}$ Arguably, then, they too form part of this widespread pattern of incorporating limping rhythms from Sufi traditions into art music and folk music repertoires.

\section{Conclusion}

\footnotetext{
${ }^{64}$ Feldman 1996: 461-2; 477-8. See also Jerome Cler's (1994) discussion of aksak rhythms in Turkish folk traditions.

${ }^{65}$ This supposition explains the lack of a consistent definition and notation of Semai in pre- $19^{\text {th }}$ century sources. Ekinci argues that a high degree of variation and spontaneity in performance practice was gradually replaced by clearly defined patterns and a strict differentiation between regular and limping styles of performance, again evidencing the historical tensions between theory and practice.
} 
This is an accepted manuscript of a book chapter published by Routledge in Tuning The Past: Theory And Practice In The Music Of The Islamic World edited by Rachel Harris and Martin Stokes on 20 November 2017, available online: https://www.routledge.com/Theory-and-Practice-in-the-Music-of-the-Islamic-World-Essays-in-Honour/HarrisStokes/p/book/9781138218314

Accepted version downloaded from SOAS Research Online: http://eprints.soas.ac.uk/25381/

Following Owen Wright's hypothesis, we may argue that historically as well as today, Central Asian maqām traditions have existed less as actual repertoires of music and more as idealised frameworks surrounding more fluid oral traditions. As Pacholcyzk notes, the Sūfyāna Musīī was theorised first in the mid- $18^{\text {th }}$ century, drawing on the Systematist school of maqām theory, and again in the mid- $20^{\text {th }}$ century, when this tradition was juxtaposed with Indian raga theory. At both points, this theorisation occurred in response to social and political pressures to intellectualise the musical practice, and it was done by superimposing existing theoretical traditions rather than by developing new ones to actually describe musical practice. ${ }^{66}$ In $20^{\text {th }}$ century Xinjiang, in the story of Turdi Akhun and the ashiq, we have clear evidence of the ways in which musicians insert new repertoire into maqām frameworks, again acting in response to new social and political forces. If we understand these practices, not as somehow exceptional or deviant, but as characteristic of the development of maqām traditions in Central Asia, this understanding of Central Asian maqām builds a picture of musical creativity, flexibility and change across multiple contexts of performance.

Even in contemporary Xinjiang, professional stage performances and ashiq singing at shrine festivals exist side by side, and they continue to influence each other. The Sūfyāna Musīqī and the On Ikki Muqam share a heritage of Central Asian musical theory, but we can see that this heritage is subject to change and is always locally interpreted and practised. The two traditions share the names of various maqām, but in terms of actual musical correspondences this may be less significant than the finer points of melodic and rhythmic style that they share. These aspects of shared style suggest links which are much more immediate in terms

\footnotetext{
${ }^{66}$ Pacholcyzk 1996: p. 120.
} 
This is an accepted manuscript of a book chapter published by Routledge in Tuning The Past: Theory And Practice In The Music Of The Islamic World edited by Rachel Harris and Martin Stokes on 20 November 2017, available online: https://www.routledge.com/Theory-and-Practice-in-the-Music-of-the-Islamic-World-Essays-in-Honour/HarrisStokes/p/book/9781138218314

Accepted version downloaded from SOAS Research Online: http://eprints.soas.ac.uk/25381/

of geography and history, and rooted in shared practices of musical performance at Sufi shrines. $20^{\text {th }}$ century national borders have interrupted historical patterns of cultural exchange in this region, and the nationalist tendency to understand these traditions in ethnically exclusive, geographically limited terms has obscured the historical links between these neighbouring traditions, but these links are still audible in contemporary performance and deserve to be better recognised and understood.

\section{References}

Algar, H., 'From Kashghar to Eyüp: The Lineages and Legacy of Sheikh Abdullah Nidai', in E. Özdalga (ed.), Naqshbandis in Western and Central Asia (Swedish Research Institute in Istanbul, 1999).

Baily, J., Music of Afghanistan: Professional Musicians in the City of Herat (Cambridge: Cambridge University Press, 1988).

Baldick, J., Mystical Islam: An Introduction to Sufism (London: Tauris, 1989). 
This is an accepted manuscript of a book chapter published by Routledge in Tuning The Past: Theory And Practice In The Music Of The Islamic World edited by Rachel Harris and Martin Stokes on 20 November 2017, available online: https://www.routledge.com/Theory-and-Practice-in-the-Music-of-the-Islamic-World-Essays-in-Honour/HarrisStokes/p/book/9781138218314

Accepted version downloaded from SOAS Research Online: http://eprints.soas.ac.uk/25381/

Bellew, H.W., Kashmir and Kashgar: A Narrative of the Journey of the Embassy to Kashgar in 1873-74 (Lahore: Sang-e-Meel Publications, 1999 [1875]).

Burckhardt Qureshi, R., Sufi Music of India and Pakistan: Sound, Context, and Meaning in Qawwali (Oxford: Oxford University Press, 2006).

Cable, M., with French, F., The Gobi Desert (London: Hodder and Stoughton, 1942).

Cler, J., 1994, 'Pour une théorie de l'aksak', Revue de Musicologie, 80/2, 181-209.

Djumaev, A., 'From Parda to Maqam: A Problem of the Origin of the Regional Systems', in J. Elsner and G. Jahnichen (eds.) Regionale Maqam: Traditionen in Geschichte und Gegenwart, vol. 1. (Study group “Maqām” of the ICTM, 1992), 145-162. , 'Najm al-Din Kaukabi Bukhari and the Maqam Theory in the $16^{\text {th }}$ to $18^{\text {th }}$ Centuries', in J. E. \& R. P. Pennanen eds. The Structure and Idea of Maqam: Historical Approaches (Tampere: University of Tampere, 1997), 27-37. 
This is an accepted manuscript of a book chapter published by Routledge in Tuning The Past: Theory And Practice In The Music Of The Islamic World edited by Rachel Harris and Martin Stokes on 20 November 2017, available online: https://www.routledge.com/Theory-and-Practice-in-the-Music-of-the-Islamic-World-Essays-in-Honour/HarrisStokes/p/book/9781138218314

Accepted version downloaded from SOAS Research Online: http://eprints.soas.ac.uk/25381/ , 'Sacred Music and Chant in Islamic Central Asia', in V. Danielson, S. Marcus and D. Reynolds (eds.), The Garland Encyclopedia of World Music, Volume 6, The Middle East (New York: Garland Publishing, 2002), 935-47.

During, J., 1997, 'Rythmes ovoïdes et quadrature du cycle', Cahiers des musiques traditionnelles, 10, 16-36.

Elias N. (ed.), A History of the Moghuls of Central Asia, Being the Tarikh-i-Rashidi of Mirza Muhammad Haidar Dughlat, trans. E. Denison Ross (London: Curzon, 1898).

Feldman, W., Music of the Ottoman Court: Makam, Composition and the Early Ottoman Instrumental Repertoire, Verlag für Wissenschaft und Bildung, 1996.

Gu B., 'Qiuciyue yu shi'er mukamu', in Xinjiang yishu bianji bu (eds.), Sichou zhilu yuewu yishu (Ürümchi: Xinjiang renmin chubanshe, 1985): 23-31.

Harris, R., The Making of a Musical Canon in Chinese Central Asia: The Uyghur Twelve Muqam (Aldershot: Ashgate Press, 2008).

, 'National Traditions and Illegal Religious Activities in Chinese Central Asia', in L. Nooshin (ed.) Sounds of Power: Music, Politics and Ideology in the Middle East, North Africa and Central Asia (Aldershot: Ashgate Press, 2009), 165-185. 
This is an accepted manuscript of a book chapter published by Routledge in Tuning The Past: Theory And Practice In The Music Of The Islamic World edited by Rachel Harris and Martin Stokes on 20 November 2017, available online: https://www.routledge.com/Theory-and-Practice-in-the-Music-of-the-Islamic-World-Essays-in-Honour/HarrisStokes/p/book/9781138218314

Accepted version downloaded from SOAS Research Online: http://eprints.soas.ac.uk/25381/

Harris, R. and Dawut, R., 2002, 'Mazar festivals of the Uyghurs: Music, Islam and the Chinese State', British Journal of Ethnomusicology, 11/1, 101-18.

Jarring, G., Dervish and Qalandar: texts from Kashghar, edited and translated, with notes and glossary (Stockholm: Almqvist \& Wiksell International, 1987).

Kaw, M. A., 2010, ‘Central Asian Contribution to Kashmir's Tradition of Religio-Cultural Pluralism', Central Asiatic Journal, 54/2, 237-255.

Koen, B., 2005, 'Medical Ethnomusicology in the Pamir Mountains: Music and Prayer in Healing', Ethnomusicology, 49/2, 287-311.

Lansdell, H., Through Central Asia: with a map and appendix on the diplomacy and delimitation of the Russo-Afghan frontier (London: British Library, Historical Print Editions, $2011[1887])$.

Light, N., Intimate Heritage: Creating Uyghur Muqam Song in Xinjiang (Berlin: Lit Verlag, 2008). 
This is an accepted manuscript of a book chapter published by Routledge in Tuning The Past: Theory And Practice In The Music Of The Islamic World edited by Rachel Harris and Martin Stokes on 20 November 2017, available online: https://www.routledge.com/Theory-and-Practice-in-the-Music-of-the-Islamic-World-Essays-in-Honour/HarrisStokes/p/book/9781138218314

Accepted version downloaded from SOAS Research Online: http://eprints.soas.ac.uk/25381/

Baytur \& Tömür (eds.), Molla Ismätulla binni Molla Nämatulla Mojizi: Tävarikhi Musiqiyun (Beijing: Minzu chubanshe, 1982).

Pacholczyk, J. M., Süfyāna Mūsīqū: The Classical Music of Kashmir (Berlin: Verlag für Wissenschaft und Bildung, 1996).

Papas A., Mystiques et Vagabonds en Islam: Portraits de trois Soufis qalandars (Paris: Cerf, Patrimoines: visages de l'Islam, 2010).

Ramsey, C., 'Rishīwaer: Kashmir, the Garden of Saints', in C. Bennett, and C. M. Ramsey (eds.) South Asian Sufis: Devotion, Deviation and Destiny (London: Continuum Books, 2012), 197-210.

Rizvi, S.A. A History of Sufism in India, vol 1. (New Delhi: Munshiram Manoharlal, 1983).

Shinjang Uyghur Aptonom Rayonluq Mädiniyät Nazariti, Uyghur Khalq Kilasik Muzikisi:

On Ikki Muqam (Beijing: Muzika Näshriyati, Millätlär Näshriyati, 1960). , Uyghur On Ikki Muqam (Ürümchi: Shinjang khälq näshriyati, 1994). 
This is an accepted manuscript of a book chapter published by Routledge in Tuning The Past: Theory And Practice In The Music Of The Islamic World edited by Rachel Harris and Martin Stokes on 20 November 2017, available online: https://www.routledge.com/Theory-and-Practice-in-the-Music-of-the-Islamic-World-Essays-in-Honour/HarrisStokes/p/book/9781138218314

Accepted version downloaded from SOAS Research Online: http://eprints.soas.ac.uk/25381/

Sumits, W., The Evolution of the Maqām Tradition in Central Asia: From the Theory of 12 Maqām to the Practice of Shashmaqām (PhD dissertation, SOAS, University of London, 2011).

Thum, R., The Sacred Routes of Uyghur History (Cambridge, MA, Harvard University Press, 2014).

Trebinjac, S., Le Pouvoir en Chantant: l'Art de Fabriquer une Musique Chinoise (Nanterre: Société d'Ethnologie, 2000).

Wright, O., The Modal System of Arab and Persian Music A.D. 1250-1300 (Oxford: Oxford University Press, 1978).

_ , 'Segāh: an historical outline', in J. Elsner and G. Jähnichen (eds.) Regionale MaqāmTraditionen in Geschichte und Gegenwart (Study group "Maqām" of the ICTM, 1992), 480509. , 1996, 'On The Concept Of A "Timurid Music"', Oriente Moderno, Nuova serie, 76/2, $665-681$. 
This is an accepted manuscript of a book chapter published by Routledge in Tuning The Past: Theory And Practice In The Music Of The Islamic World edited by Rachel Harris and Martin Stokes on 20 November 2017, available online: https://www.routledge.com/Theory-and-Practice-in-the-Music-of-the-Islamic-World-Essays-in-Honour/HarrisStokes/p/book/9781138218314

Accepted version downloaded from SOAS Research Online: http://eprints.soas.ac.uk/25381/

Zarcone, T., 'Sufi Lineages and Saint Veneration in 20th Century Eastern Turkestan and Contemporary Xinjiang', in H. Celâl Guzel, C. Oguz and O. Karatay (eds.) The Turks (Istanbul: Yeni Turkiye Publications, 2002), 534-41.

Zhou J., Nawa mukamu (Ürümchi: Xinjiang yishu yanjiusuo, 1995). , Zhongguo Xinjiang Weiwu'erzu Yisilanjiao liyi yinyue (Taipei: Xinwenfeng chuban gongsi, 1999). 